Chapter 4

\title{
Genes Involved in Type 1 Diabetes
}

\author{
Marina Bakay, Rahul Pandey and \\ Hakon Hakonarson \\ Additional information is available at the end of the chapter \\ http://dx.doi.org/10.5772/52435
}

\section{Introduction}

The prevalence of diabetes is increasing worldwide and to date it impacts the lives of approximately 200 million people (Steyn et al., 2009). It is estimated that by 2030, there will be 439 million adults affected by diabetes (International Diabetes Federation/diabetes prevalence: www.idf.org). Type 1 diabetes (T1D) represents approximately $10 \%$ of these patients and is most prevalent in populations of European ancestry, where there is ample evidence of increased annual incidence during the past five decades (Onkamo et al., 1999; EURODIAB ACE Study Group, 2000).

T1D is a complex trait that results from the interplay between environmental and genetic factors. Much evidence supports a strong genetic component associated with T1D. The epidemiological data showing differences in geographic prevalence is one clear indicator, with populations of European ancestry having the highest presentation rate. T1D has high concordance among monozygotic twins (33 to 42\%) (Redondo et al., 2001) and runs strongly in families with sibling risk being approximately 10 times greater than in the general population (Clayton, 2009); this is in clear contrast to the "less genetic" type 2 diabetes, where the sibling risk ratio is relatively modest at 3.5 (Rich, 1990).

T1D develops at all ages and occurs through the autoimmune destruction of pancreatic $\beta$-cells with resulting lack of insulin production. The immune system participates in $\beta$-cell destruction through several of its components including natural killer (NK) cells, B lymphocytes, macrophages, dendritic cells (DC), and antigen-presenting cells (APCs). Studies in human and animal models have shown that both innate and adaptive immune responses participate in disease pathogenesis, possibly reflecting the multifactorial nature of this autoimmune disorder. 
In this review, we provide an update on genome-wide association studies (GWAS) discoveries to date and discuss the latest associated regions added to the growing repertoire of gene networks predisposing to T1D.

\section{Genetic component in Type 1 diabetes}

\subsection{Before genome-wide association studies}

Historically, prior to GWAS, only six loci had been fully established to be associated with T1D. The human leukocyte antigen (HLA) region on chromosome 6p21 was the first known candidate to be strongly associated with T1D in 1970s (Singal \& Blajchman, 1973; Nerup et al., 1974; Cudworth \& Woodrow, 1975). This cluster of homologous cell-surface proteins is divided into class I (A, B, C) and class II (DP, DQ, RD). The HLA genes encode highly polymorphic proteins, which are essential in self versus non-self immune recognition. The class I molecules are ubiquitously expressed and present intracellular antigen to $\mathrm{CD} 8^{+} \mathrm{T}$ cells. Class II molecules are expressed mainly on professional APCs: DCs, macrophages, B-lymphocytes and thymus epithelium. Class II molecules are composed of A and B chains, and present antigens to $\mathrm{CD}^{+} \mathrm{T}$ cells, which promote inflammation by secreting cytokines upon recognition of their specific targets. Approximately half of the genetic risk for T1D is conferred by the genomic region harboring the HLA class II genes primarily HLA-DRB1, -DQA1 and -DQB1 genes). In 1984, insulin (INS) gene encoded on chromosome 11p15 was identified as second loci linked with T1D (Bell et al., 1984). In 1996, the cytotoxic T-lymphocyte-associated protein 4 (CTLA4) gene encoded on chromosome 2q33 was recognized as third loci (Nistico et al., 1996). In 2004, a protein tyrosine phosphatase, non-receptor type 22 (PTPN22) gene encoded on chromosome 1p13, was found to be associated with susceptibility to T1D in another case-control study (Bottini et al., 2004). Vella et al., 2005 reported interleukin 2 receptor alpha (IL2RA) gene as fifth T1D loci on chromosome 10p15. In 2006, Smyth et al. identified the interferon-induced with helicase C domain 1 (IFIH1) gene on chromosome 2q24.3 as the sixth gene to be strongly associated with T1D.

\subsection{GWAS of T1D}

The advent of GWAS in the mid-2000s has changed the situation dramatically, increasing the pace and efficiency of discovery for the T1D associated loci, by a factor of ten. The critical platform for this work was laid by the HapMap project (International HapMap Consortium, 2003 , 2005). The GWAS approach has been made possible by the development of high-density genotyping arrays. The genome is laid out in discrete linkage disequilibrium (LD) blocks with limited haplotype diversity within each of these blocks. Therefore, a minimal set of single nucleotide polymorphisms (SNPs) can detect almost all common haplotypes present, thus improving genotyping accuracy and reducing cost.

The first full-scale GWAS for T1D were published in 2007 by our group (Hakonarson et al., 2007) and The Wellcome Trust Case-Control Consortium (WTCCC, 2007). We examined a large pediatric cohort of European descent using the Illumina HumanHap 550 BeadChip platform. 
The design involved 561 cases, 1,143 controls and 467 triads in the discovery stage, followed by a replication effort in 939 nuclear families. In addition to finding the "usual" suspects, including an impressive 392 SNPs capturing the very strong association across the major histocompatibility complex (MHC), we identified significant association with variation at the KIAA0350 gene, which we replicated in an additional cohort. The WTCCC study investigated seven common complex diseases including T1D by genotyping 2,000 cases and 3,000 controls with 500,000 SNPs using the Affymetrix GeneChip, and reported a number of novel T1D loci, including the KIAA0350 genomic region (WTCCC, 2007). Todd et al., 2007 confirmed these findings, using 4,000 cases, 5,000 controls and 3,000 T1D families as well as association reported in the WTCCC study to the $12 \mathrm{q} 13$ region. In a separate effort we fast-tracked 24 SNPs at 23 distinct loci from our original study and established association to the $12 \mathrm{q} 13$ region with a combined $P$-value of $9.13 \times 10^{-10}$ (Hakonarson et al., 2008); this was the same locus as reported by the WTCCC and Todd et al., 2007. The 12q13 region harbors several genes, including ERBB3, RAB5B, SUOX, RPS26 and CDK2. However, the causative variants at this locus remain unknown. Concannon et al., 2008 reported an association between SNP at the UBASH3A locus on 21q22.3 and T1D by using SNP genotyping data from a linkage study of affected sib pairs in nearly 2,500 multiplex families, a finding also corroborated by our efforts as well as association to the BACH2 gene (Grant et al., 2009).

\subsection{Meta-analyses of T1D GWAS datasets}

In order to get the most from GWAS and to increase the statistical power, several independent research groups carried out meta-analyses using datasets from different investigative groups. Cooper et al., 2008 performed the first meta-analysis by using T1D datasets from the WTCCC, 2007 and the Genetics of Kidneys in Diabetes (GoKind) study (Mueller et al, 2006; Manolio et al., 2007), and confirmed associations for PTPN22, CTLA4, MHC, IL2RA, 12q13, 12q24, CLEC16A and PTPN2. The SNPs with lowest nominal $P$-values were taken forward for further genotyping in an additional British cohort of 6,000 cases, 7,000 controls and 2,800 families. As a result, the IL2-IL21 association strengthened further and they found strong evidence for four additional loci: $\mathrm{BACH} 2$; a 10p15 region harboring the protein kinase $\mathrm{C}$, theta gene (PRKCQ); a 15q24 region harboring nine genes including cathepsin $\mathrm{H}(\mathrm{CTSH})$ and a 22q13 region harboring tumor necrosis factor related protein 6 (C1QTNF6). Additional studies are required to elucidate the culprit genes and their mechanism at the 15q24 and 22q13 loci.

Barrett et al., 2009 meta-analysis uncovered in excess of 40 loci, including 18 novel regions, plus they confirmed a number of previously reported (Smyth et al., 2008; Fung et al., 2009; Cooper et al., 2009). The study included samples from WTCCC, 20070, the GoKind study (Mueller et al., 2006) and controls and family sets from Type 1 Diabetes Genetics Consortium (T1DGC). The meta-analysis observed association to 1q32.1 (which harbors the immunoregulatory interleukin genes IL10, IL19 and IL20), 9p24.2 contains only Glis family zinc finger protein 3 (GLIS3; first suggested by us in Grant et al., 2009), 12p13.31 which harbors a number of immunoregulatory genes including CD69 and 16p11.2 harboring IL27. These findings were further supported by our in silico replication efforts (Qu et al., 2010). 
To identify additional genetic loci for T1D susceptibility, we examined associations in the largest meta-analysis to date between the disease and $\sim 2.54$ million genotyped and imputed SNPs in a combined cohort of 9,934 cases and 16,956 controls (Bradfield et al., 2011). Targeted follow-up of 53 SNPs in 1,120 affected trios uncovered three new loci associated with T1D that reached genome wide significance. The most significantly associated SNP (rs539514, P = $5.66 \times 10^{-11}$ ) resided in an intronic region of the LMO7 (LIM domain only 7) gene on 13q22. The second most significantly associated SNP $\left(\mathrm{rs} 478222, P=3.50 \times 10^{-9}\right)$ resided in an intronic region of the EFR3B (protein EFR3 homolog B) gene on 2p23; however the region of linkage disequilibrium is approximately $800 \mathrm{~kb}$ and harbors additional multiple genes, including NCOA1, C2orf79, CENPO, ADCY3, DNAJC27, POMC, and DNMT3A. The third most significantly associated SNP (rs924043, $\left.P=8.06 \times 10^{-9}\right)$ was in an intergenic region on $6 \mathrm{q} 27$, where the region of association is approximately $900 \mathrm{~kb}$ and harbors additional genes including WDR27, C6orf120, PHF10, TCTE3, C6orf208, LOC154449, DLL1, FAM120B, PSMB1, TBP and PCD2. These latest associations add to the growing repertoire of gene networks predisposing to T1D. Table 1 summarizes all T1D associated loci reported to date.

\begin{tabular}{|c|c|c|c|c|c|}
\hline Reference & Sample Size & $\begin{array}{l}\text { Replication } \\
\text { Sample Size }\end{array}$ & Ethnic Group & Study Type & Main Findings \\
\hline $\begin{array}{l}\text { Hakonarson et al., } \\
2007\end{array}$ & $\begin{array}{c}467 \text { trios, } \\
561 \text { cases, } \\
1,143 \text { controls }\end{array}$ & $\begin{array}{l}\text { 2,350 individuals in } \\
549 \text { families; } \\
390 \text { trios }\end{array}$ & $\begin{array}{l}\text { European } \\
\text { ancestry }\end{array}$ & GWAS & $\begin{array}{c}\text { HLA-DRB1, } \\
\text { HLA-DQA2, CLEC16A, } \\
\text { INS, PTPN22 }\end{array}$ \\
\hline WTCCC 2007 & $\begin{array}{c}1,963 \text { cases, } \\
2,938 \text { controls }\end{array}$ & see Todd et al., 2007 & $\begin{array}{l}\text { European, } \\
\text { British }\end{array}$ & GWAS & $\begin{array}{l}\text { HLA-DRB1, INS, CTLA4, } \\
\text { PTPN22, IL2RA, IFIH1, } \\
\text { PPARG, KCNJ11, } \\
\text { TCF7L2 }\end{array}$ \\
\hline Todd et al., 2007 & $\begin{array}{c}\text { see WTCCC } \\
2007\end{array}$ & $\begin{array}{c}2997 \text { trios, 4,000 } \\
\text { cases, 5,000 controls }\end{array}$ & $\begin{array}{l}\text { European } \\
\text { British }\end{array}$ & GWAS & $\begin{array}{c}\text { PHTF1-PTPN22, ERBB3, } \\
\text { CLEC16A, C12orf30 }\end{array}$ \\
\hline $\begin{array}{l}\text { Hakonarson et al., } \\
2008\end{array}$ & $\begin{array}{l}467 \text { trios, } 561 \\
\text { cases, 1,143 } \\
\text { controls }\end{array}$ & $\begin{array}{c}549 \text { families, } 364 \\
\text { trios }\end{array}$ & $\begin{array}{l}\text { European } \\
\text { ancestry }\end{array}$ & GWAS & SUOX - IKZF4 \\
\hline $\begin{array}{l}\text { Concannon et al., } \\
2008\end{array}$ & 2,496 families & $\begin{array}{c}2,214 \text { trios, } 7,721 \\
\text { cases, } 9,679 \text { controls }\end{array}$ & $\begin{array}{l}\text { European } \\
\text { ancestry }\end{array}$ & GWAS & $\begin{array}{c}\text { INS, IFIH1, CLEC16A, } \\
\text { UBASH3A }\end{array}$ \\
\hline Cooper et al., 2008 & $\begin{array}{c}3,561 \text { cases, } \\
4,646 \text { controls }\end{array}$ & $\begin{array}{l}6,225 \text { cases, } 6,946 \\
\text { controls, 3,064 trios }\end{array}$ & $\begin{array}{l}\text { European } \\
\text { ancestry }\end{array}$ & $\begin{array}{c}\text { GWAS meta- } \\
\text { analysis }\end{array}$ & $\begin{array}{c}\text { PTPN22, CTLA4, HLA, } \\
\text { IL2RA, ERRB3, } \\
\text { C12orf30, } \\
\text { CLEC16A, PTPN2 }\end{array}$ \\
\hline Grant et al., 2009 & $\begin{array}{c}563 \text { cases, } \\
1,146 \text { controls, } \\
483 \text { case- } \\
\text { parents trios }\end{array}$ & $\begin{array}{l}636 \text { families, 3,303 } \\
\text { cases, 4,673 controls }\end{array}$ & $\begin{array}{l}\text { European } \\
\text { ancestry }\end{array}$ & GWAS & $\begin{array}{l}\text { EDG7, BACH2, GLIS3, } \\
\text { UBASH3A, RASGRP1 }\end{array}$ \\
\hline
\end{tabular}




\begin{tabular}{|c|c|c|c|c|c|}
\hline Reference & Sample Size & $\begin{array}{l}\text { Replication } \\
\text { Sample Size }\end{array}$ & Ethnic Group & Study Type & Main Findings \\
\hline Awata et al., 2009 & $\begin{array}{l}735 \text { cases, } \\
621 \text { controls }\end{array}$ & - & Japanese & $\begin{array}{c}\text { TaqMan } \\
\text { genotyping }\end{array}$ & ERBB3, CLEC16A \\
\hline $\begin{array}{c}\text { Zoledziewska et } \\
\text { al., } 2009\end{array}$ & $\begin{array}{l}1037 \text { cases, } \\
1706 \text { controls }\end{array}$ & - & $\begin{array}{l}\text { European, } \\
\text { Sardinian }\end{array}$ & $\begin{array}{c}\text { TaqMan } \\
\text { genotyping }\end{array}$ & CLEC16A \\
\hline Fung et al., 2009 & $\begin{array}{l}8010 \text { cases, } \\
9733 \text { controls }\end{array}$ & - & $\begin{array}{c}\text { European, } \\
\text { British }\end{array}$ & $\begin{array}{c}\text { TaqMan } \\
\text { genotyping }\end{array}$ & $\begin{array}{c}\text { STAT4, STAT3, ERAP1, } \\
\text { TNFAIP3, KIF5A/ } \\
\text { PIP4K2C }\end{array}$ \\
\hline Wu et al., 2009 & $\begin{array}{l}205 \text { cases, } \\
422 \text { controls }\end{array}$ & - & Han Chinese & $\begin{array}{c}\text { TaqMan } \\
\text { genotyping }\end{array}$ & CLEC16A \\
\hline Barrett et al., 2009 & $\begin{array}{l}\text { 7,514 cases, } \\
9,045 \text { controls }\end{array}$ & $\begin{array}{l}\text { 4,267 cases, 4,670 } \\
\text { controls, 4,342 trios }\end{array}$ & European & $\begin{array}{l}\text { GWAS meta- } \\
\text { analysis }\end{array}$ & $\begin{array}{l}\text { MHC, PTPN22, INS, } \\
\text { C10orf59, SH2B3, } \\
\text { ERBB3, CLEC16A, } \\
\text { CTLA4, PTPN2, IL2RA, } \\
\text { IL27, C6orf173, IL2, } \\
\text { ORMDL3, GLIS3, CD69, } \\
\text { IL10, IFIH1, UBASH3A, } \\
\text { COBL, BACH2, CTSH, } \\
\text { PRKCQ, C1QTNF6, } \\
\text { PGM1 }\end{array}$ \\
\hline $\begin{array}{l}\text { Wallace et al., } \\
\qquad 2010\end{array}$ & $\begin{array}{l}7,514 \text { cases, } \\
9,045 \text { controls }\end{array}$ & $\begin{array}{l}\text { 4,840 cases, } 2,670 \\
\text { controls, 4,152 trios }\end{array}$ & $\begin{array}{l}\text { European } \\
\text { ancestry }\end{array}$ & $\begin{array}{l}\text { GWAS meta- } \\
\text { analysis }\end{array}$ & DLK1, TYK2 \\
\hline Wang et al., 2010 & $\begin{array}{c}989 \text { cases, } 6197 \\
\text { controls }\end{array}$ & - & $\begin{array}{l}\text { European } \\
\text { ancestry }\end{array}$ & GWAS & $\begin{array}{l}\text { PTPN22, IL10, IFIH1, } \\
\text { KIAA0746, BACH2, } \\
\text { C6orf173, TAGAP, } \\
\text { GLIS3, L2R, INS, ERBB3, } \\
\text { C14orf181, IL27, } \\
\text { PRKD2, HERC2, } \\
\text { CLEC16A, IFNG, IL26, }\end{array}$ \\
\hline Reddy et al., 2011 & $\begin{array}{l}1434 \text { cases, } \\
1864 \text { controls }\end{array}$ & - & $\begin{array}{c}\text { European } \\
\text { ancestry, } \\
\text { southeast USA }\end{array}$ & $\begin{array}{c}\text { TaqMan } \\
\text { genotyping }\end{array}$ & $\begin{array}{c}\text { PTPN22, INS, IFIH1, } \\
\text { SH2B3, ERBB3, CTLA4, } \\
\text { C14orf181, CTSH, } \\
\text { CLEC16A, CD69, ITPR3, } \\
\text { C6orf173, SKAP2, } \\
\text { PRKCQ, RNLS, IL27, } \\
\text { SIRPG, CTRB2 }\end{array}$ \\
\hline $\begin{array}{l}\text { Bradfield et al., } \\
2011\end{array}$ & $\begin{array}{c}\text { 9,934 cases, } \\
16,956 \text { controls }\end{array}$ & 1,120 trios & $\begin{array}{l}\text { European } \\
\text { ancestry }\end{array}$ & $\begin{array}{l}\text { GWAS meta- } \\
\text { analysis }\end{array}$ & $\begin{array}{c}\text { LMO7, EFR3B, 6q27, } \\
\text { TNFRSF11B, }\end{array}$ \\
\hline
\end{tabular}




\begin{tabular}{cccccc}
\hline Reference & Sample Size & $\begin{array}{c}\text { Replication } \\
\text { Sample Size }\end{array}$ & Ethnic Group & Study Type & Main Findings \\
& & & & LOC100128081, \\
& & & FOSL2 \\
\hline Asad et al., 2012 & $\begin{array}{c}424 \text { families, } \\
3078 \text { cases, }\end{array}$ & - & Scandinavians & and & HTR1A, RFN180 \\
& 1363 controls & & sequencing & CUX2, IL2RA \\
\hline Huang et al., 2012 & 16,179 & European & Genomes- & based & \\
& individuals & & ancestry & imputation & \\
\hline
\end{tabular}

Table 1. T1D susceptibility loci identified to date.

\subsection{Immune components in T1D}

The immune system is well organized and well regulated with a basic function of protecting the host against pathogens. This places the immune system in a vital position between healthy and diseased states of the host. Its protective task is regulated by a complex regulatory mechanism involving a diverse army of cells and molecules of humoral and cellular factors working in concert to protect the body against invaders. The human immune system has two components: innate and adaptive. Innate immunity is comprised of physical, chemical, and microbiological barriers to the entry of antigen, and the elements of immune system (DC, macrophages, mast cells, NK cells, neutrophils, monocytes, complements, cytokines and acute phase proteins), which provide immediate host defense. Adaptive immunity is the hallmark of the immune system of higher animals with $\mathrm{T}$ and B cells as the key cellular players that provide more specific life-long immunity.

In T1D this system breaks down: insulin-producing $\beta$-cells are subjected to specific attack by the host immune system. To better understand the etiology of T1D, a plethora of research has been done to link the systematic destruction of $\beta$-cells and the role of the immune system. Linkage studies in 1970s revealed MHC as the first key contributor to T1D susceptibility. Further linkage analysis and candidate gene association studies revealed additional loci associated with T1D. Starting in 2007, GWAS have increased the number of loci be associated with T1D to almost 60. In Figure 1 we present 59 T1D susceptibility loci as where we have classified them into loci harboring non-immune (14) vs. immune (45) genes. Functional aspects of some genes are discussed below.

The complex crosstalk between innate and adaptive immune cells has major impact on the pathogenesis and development of T1D as illustrated in Figure 2. The initiation phase (Phase I) of T1D development takes place in the pancreas where conventional dendritic cells (cDCs) capture and process $\beta$-cell antigens. Apoptosis ('natural cell death') or viral infection can lead to $\beta$-cell death. Antiviral responses are mediated by invariant natural killer T (iNKT) cells; crossplay between iNKT and plasmacytoid DCs (pDCs) controls viral replication thus prevents subsequent inflammation, tissue damage, and downregulating T1D pathogenesis. 
Migration of activated cDCs to the draining lymph node primes pathogenic islet antigenspecific T cells. This activation is promoted by macrophages through IL12 secretion. B cells present $\beta$-cell antigen to diabetogenic T cells and secrete autoantibodies in response. The activation of islet antigen-specific T cells can be inhibited by cDCs through engagement of programmed cell death ligand 1 (PDL1). The expansion phase (Phase II): iNKT cells can further promote the recruitment of tolerogenic cDCs and pDCs. These DCs promote expansion of regulatory $\mathrm{T}$ (TReg) cells through the production of indoleamine 2,3-dioxygenase (IDO), IL10, transforming growth factor- $\beta$ (TGF $\beta$ ) and inducible $\mathrm{T}$ cell co-stimulator ligand (ICOSL). Phase III: In the pancreas, $\beta$-cell can be killed by diabetogenic T cells and NK cells through the release of interferon- $\gamma$ (IFN $\gamma)$, granzymes and perforin, as well as by macrophages through the production of tumour necrosis factor (TNF), IL-1 $\beta$ and nitric oxide (NO). IL12 produced by cDCs sustains the effector functions of activated diabetogenic T cells and NK cells. TReg cells that inhibit diabetogenic $\mathrm{T}$ cells and innate immune cells through IL10 and TGF $\beta$ can prevent $\beta$-cell damage. Tolerogenic pDCs stimulated by iNKT cells could also control diabetogenic T cells through IDO production. Lastly, $\beta$-cells can inhibit diabetogenic T cells by expressing PDL1 and escape the cell death.

\section{A. Non-immune Genes}

\section{B. Immune Genes}

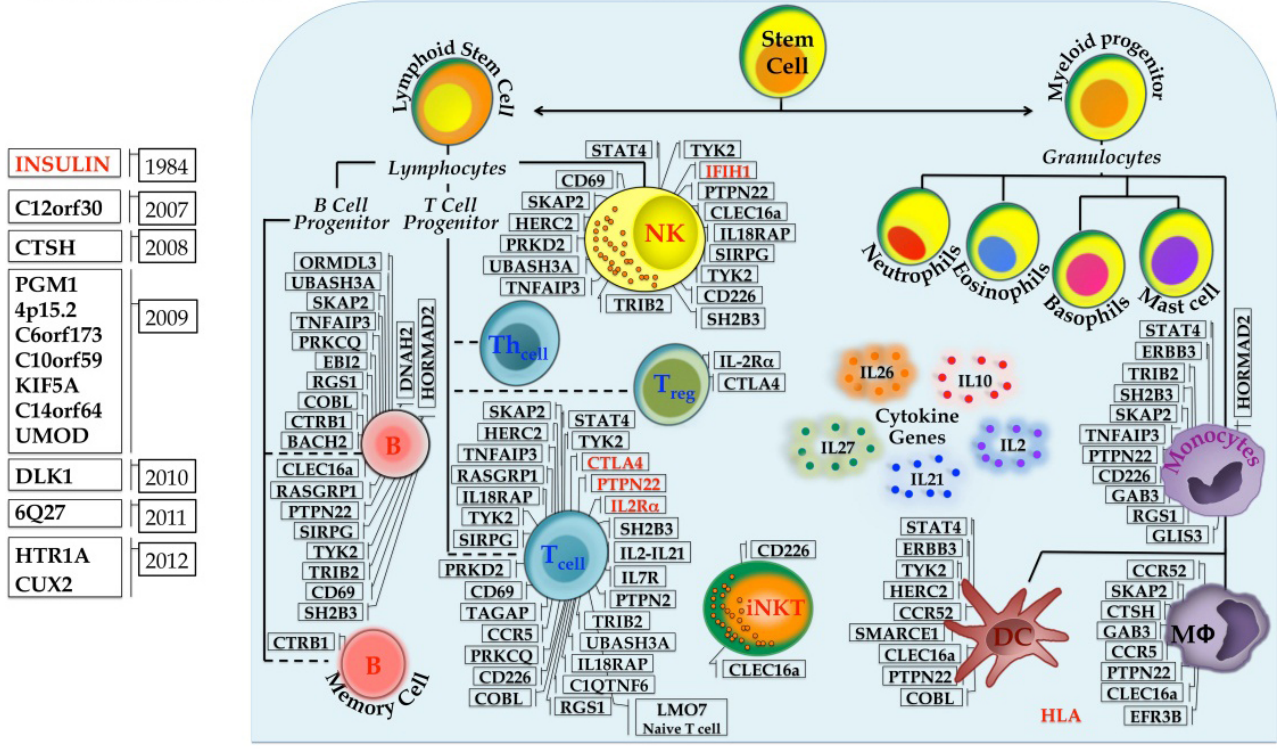

Figure 1. Immune and Non-immune T1D genes are depicted in a concept map representing the components of the immune system. The discovery of T1D susceptibility genes started as early as 1974 with just six genes identified by 2006 shown in red. The advent of GWAS led to flurry of novel genes associated with T1D reaching the excess of 40 by 2009 and almost 60 by 2012. 


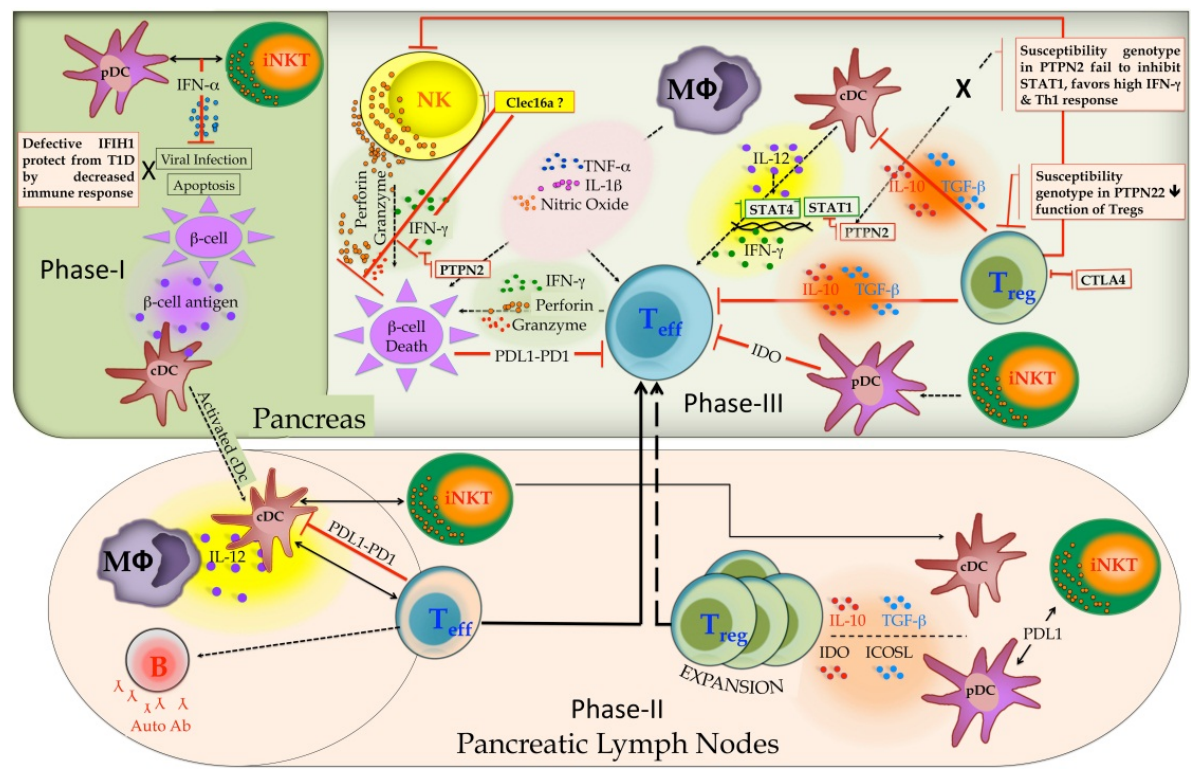

Figure 2. Pathogenesis model of T1D involves complex interactions between innate and adaptive immune cell types.

\subsection{CLEC16A (16p13)}

The C-type lectin domain family 16, member A (CLEC16A) gene encodes protein with C-type lectin domain structure, which makes it potentially related to the immune response (Robinson et al., 2006). It is established that C-type lectins function both as adhesion and pathogen recognition receptors (PPRs) (Cambi \& Figdor, 2003). In addition, CLEC16A is almost exclusively expressed in immune cells including DCs, B-lymphocytes and NK cells. Our 2007 GWAS in a large pediatric cohort of European descent identified CLEC16A as a novel T1D susceptibility gene within a 233-kb linkage disequilibrium block on chromosome 16p13. Three common non-coding variants of the CLEC16A gene (rs2903692, rs725613 and rs17673553) reached genome-wide significance for association with T1D (Hakonarson et al., 2007). Subsequent replication studies in an independent cohort confirmed the association. Importantly, the allele of CLEC16A linked to protection from T1D was also associated with higher levels of CLEC16A expression in NK cells (Hakonarson et al., 2007).

The 2007 WTCCC study independently discovered CLEC16A (formally known as KIAA0350) as a T1D susceptibility locus associated with the non-coding variant rs12708716. This finding was confirmed immediately for T1D in populations of European descent (Todd et al., 2007, Cooper et al., 2008). To date, several SNPs (rs2903692, rs17673553, rs725613, rs12708716, rs12921922, rs12931878) within the CLEC16A gene have been reported to be associated with T1D in several populations: Sardinian (Zoledziewska et al., 2009), Spanish (Martinez et al., 2010), southeast USA (Reddy et al., 2011), Chinese (Wu et al., 2009; Sang et al., 2012), and 
Japanese (Yamashita et al., 2011). Recently CLEC16A was also associated with adult-onset of autoimmune diabetes (Howson et al., 2011).

Several GWAS in different autoimmune diseases such as multiple sclerosis (MS) (Zuvich, 2011; Nischwitz et al., 2011), Addison's disease (Skinningsrud et al., 2008), systemic lupus erythematosus (SLE) (Gateva et al., 2009; Zhang et al., 2011), Celiac disease (Dubois et al., 2010), Crohn's disease (Márquez et al., 2009), selective immunoglobulin A deficiency (Jagielska et al., 2012), alopecia areata (Jagielska et al., 2012), rheumatoid arthritis (Martinez et al., 2010) and primary biliary cirrhosis (Mells et al., 2011; Hirschfield et al., 2012) also demonstrated association of the $16 \mathrm{p} 13$ loci with disease risk, implying that the $16 \mathrm{p} 13$ region contains a key regulator of the self-reactive immune response.

Recently, Davison et al., 2012 reported intron 19 of the CLEC16A gene behaves as a regulatory sequence, which affects the expression of a neighboring gene dexamethasone-induced (DEXI). While it is clear that intron 19 of CLEC16A is highly enriched for transcription-factor-binding events, more functional studies are needed to advance from GWAS to candidate causal genes and their biological functions.

To find causal variant of CLEC16A gene we sequenced the 16p13 region in 96 T1D patients and found 10 new non-synonymous SNPs resulting in one stop-codon, two splice site mutations, and 7 amino acid changes (unpublished data). The studies are under way to examine if these changes are correlated with CLEC16A expression and if these SPNs are present in control group.

Little is yet proven about CLEC16A functions. Kim et al., 2010 characterized ema as an endosomal membrane protein is required for endosomal trafficking and promotes endosomal maturation. Expression of human orthologue of ema 'CLEC16A' rescued the Drosophila mutant demonstrating conserved function of the protein. A recent study by the same group also reported its requirement for the growth of autophagosomes and proposed that the Golgi is a membrane source for autophagosomal growth, and that ema facilitates this process (Kim et al., 2012). Expression of CLEC16A rescued the autophagosome size defect in the ema mutant, suggesting that regulation of autophagosome morphogenesis may be one of the fundamental functions of CLEC16A. Another recent study elucidated the dynamic expression changes and localization of CLEC16A in lipopolysaccharide (LPS) induced neuroinflammatory processes in adult rats. CLEC16A expression was strongly induced in active astrocytes in inflamed cerebral cortex. In vitro studies indicated that the up-regulation of CLEC16A might be involved in astrocyte activation following LPS challenge (Wu et al., 2012).

\subsection{Other novel T1D susceptibility loci (2011-2012)}

In our latest effort to identify additional genetic loci for T1D, we examined associations in the largest meta-analysis to date between T1D and 2.54 million SNPs in a combined cohort of 9,934 cases and 16,956 controls. Targeted follow-up of 53 SNPs in 1,120 affected trios uncovered three novel loci associated with T1D that reached genome-wide significance (Bradfield et al., 2011).

LMO7 (13q22): The most significantly associated SNP (rs539514, $P=5.66 \times 10^{-11}$ ) resides in an intronic region of the LMO7 (LIM domain only 7) gene on 13q22 (Bradfield et al., 2011). LMO7 
is a multi-domain mammalian protein with a calponin homology $(\mathrm{CH})$ domain, a discs-large homologous regions (DHR) domain, and a LIM domain. Proteins of this family are involved in protein-protein interactions, regulation of cell adhesion and signaling (Ooshio et al., 2004; Yamada et al., 2004). The expression of LMO7 is cell type specific (Furuya et al., 2002; Kang et al., 2000; Lindvall et al., 2005; Bradfield et al., 2011; Rozenblum et al., 2002; Sasaki et al., 2003) and is essential for the development of muscle and heart tissues. Mice with homozygous deletions of LMO7 display retinal, muscular, and growth retardation (Semenova et al., 2003). LMO7 is upregulated in multiple cancers, especially at the metastatic stage; however under normal conditions its expression is low and limited to very few tissues (Furuya et al., 2002; Kang et al., 2000; Sasaki et al., 2003; Perou et al., 2000). In cultured rat ascites hepatoma cells, the upregulation of LMO7 correlates with the ability of transforming growth factor $\beta$ (TGF $\beta$ ) to enhance the invasiveness of these cells (Nakamura et al., 2005). Recent GWAS meta-analysis by Bradfield et al., 2011 identified LMO7 association with T1D. Although the function of LMO7 does not clearly relate to the etiology of T1D, LMO7 is expressed in pancreatic islets and thus is a possible biological candidate at this locus (Kutlu et al., 2009).

EFR3B (2q23): The second most significantly associated SNP among the new loci (rs478222, $P=3.50 \times 10^{-9}$ ) resides in an intronic region of the EFR3B (protein EFR3 homolog B) gene on 2p23; however, the region of linkage disequilibrium is approximately $800 \mathrm{~kb}$ and harbors additional multiple genes, including NCOA1, C2orf79, CENPO, ADCY3, DNAJC27, POMC, and DNMT3A. EFR3B is an 817 amino acid protein that exists as three alternatively spliced isoforms and belongs to the EFR3 family. The gene encoding EFR3B maps to human chromosome 2p23.3. A number of genetic diseases have been linked to genes on chromosome 2 including Harlequin icthyosis, lipid metabolic disorder sitosterolemia, and Alstrom syndrome. Our recent study shows novel association of 2q23 locus with T1D risk. Location of SNP rs478222 in the intronic region of EFR3B gene makes it a good candidate, however the 2 q23 region harbors additional multiple genes, including NCOA1, C2orf79, CENPO, ADCY3, DNAJC27, POMC, and DNMT3A.

Nuclear receptor coactivator 1 (NCOA1) protein is a member of the p160/steroid receptor coactivator (SRC) family. The product of this gene binds to a variety of nuclear hormone receptors in a ligand-dependent manner, suggesting that NCOA1 may play a role as a bridging molecule between nuclear hormone receptors and general transcription factors (Onate et al., 1995; Torchia et al., 1997).

C2orf79 is peptidyl-tRNA hydrolase domain containing 1 (PTRHD1) predicted protein with unknown function.

Centromere protein O (CENPO) gene encodes a component of the interphase centromere complex. The protein is localized to the centromere throughout cell division and is required for bipolar spindle assembly, chromosome segregation and checkpoint signaling during mitosis (Okada et al., 2006).

Adenylate cyclase 3 (ADCY3) gene encodes a membrane-associated enzyme. This protein catalyzes the formation of the secondary messenger cyclic adenosine monophosphate (cAMP) and is highly expressed in human placenta, testis, ovary, and colon (Ludwig \& Seuwen, 
2002). Wong et al., 2000 reported the presence of adenylyl cyclase 2, 3, and 4 in olfactory cilia. ADCY3 mutants failed olfaction-based behavioral tests indicating that ADCY3 and cAMP signaling are critical for olfactory-dependent behavior.

DnaJ/Hsp40 homolog, subfamily C, member 27 (DNAJC27) gene encodes 273 amino acid protein with RAB-like GTPase and DNAJ domains. EST database suggests high expression in nervous system and reproductive organs (Nepomuceno-Silva et al., 2004).

Pro-opiomelanocortin (POMC) gene encodes a polypeptide hormone precursor protein synthesized mainly in corticotroph cells of the anterior pituitary. POMC is essential for normal steroidogenesis and maintenance of adrenal weight. Mutations in this gene have been associated with early onset obesity, adrenal insufficiency, and red hair pigmentation (Krude et al., 1998; Hung et al., 2012).

DNA (cytosine-5)-methyltransferase 3 alpha (DNMT3A) gene encodes a protein that functions as a de-novo methyltransferase that can methylate unmethylated and hemimethylated DNA with equal efficiencies (Yanagisawa et al., 2002).

Additional fine gene mapping and functional studies are needed to determine causal variants for $2 \mathrm{q} 23$ region and their role in T1D.

Intergenic region 6q27: Intergenic region on $6 \mathrm{q} 27$ contained the third most significantly associated SNP (rs924043, $P=8.06 \times 10^{-9}$ ) in our recent study (Bradfield et al., 2011). The region of association is approximately $900 \mathrm{~kb}$ and harbors multiple genes including PHF10, TCTE3, DLL1, FAM120B, PSMB1, TBP, and PDCD2. The 6q27 region also includes several genes of unknown function: C6orf208/LINC00574 (long intergenic non-protein coding RNA 574), Tcomplex-associated-testis-expressed 3 (TCTE3), LOC154449, WD repeat domain 27 (WDR27) and chromosome 6 open reading frame 120 (C6orf120).

Plant Homeo Domain (PHD) finger protein 10 (PHF10) encodes a subunit of an ATP-dependent chromatin-remodeling complex that functions in neural precursor cells (Yoo et al., 2009).

Delta-like 1-Drosophila (DLL1) is a human homolog of the Notch Delta ligand and a member of the delta/serrate/jagged family. It plays a role in mediating cell fate decisions during hematopoiesis and cell communication (Santos et al., 2007; Dontje et al., 2006). The protein is expressed in heart, pancreas and brain. Su et al., 2006 reported pancreatic regeneration in chronic pancreatitis requires activation of the notch-signaling pathway.

Family with sequence similarity 120B (FAM120B) gene encodes protein belonging to the constitutive coactivator of peroxisome proliferator-activated receptor gamma (PPARG) family. FAM120B functions in adipogenesis through PPARG activation in a ligand-independent manner (Li et al., 2007).

Proteasome (prosome, macropain) subunit, beta type, 1 (PSMB1) gene encodes a member of the proteasome B-type family, also known as the T1B family, that is a $20 \mathrm{~S}$ core beta subunit (Trachtulec et al., 1997). This gene encodes TBP, the TATA-binding protein a transcription factor that functions at the core of the DNA-binding multiprotein transcription factor IID (TFIID). Binding of TFIID to TBP is the initial transcriptional step of the pre-initiation complex 
(PIC) and plays a role in the activation of eukaryotic genes transcribed by RNA polymerase II (Keutgens et al., 2010).

Programmed cell death 2 (PDCD2) gene encodes a nuclear protein highly expressed in placenta, heart, pancreas, lung, and liver, and lowly expressed in spleen, lymph nodes, and thymus. Expression of this gene is known to be repressed by B-cell CLL/lymphoma 6 (BCL6); a transcriptional repressor (Agata et al., 1996).

In addition, despite not reaching the genome wide significance, our study observed evidence for association at three additional loci containing the candidate genes LOC100128081, TNFRSF11B and FOSL2 (Bradfield et al., 2011). Of these, it is notable that the tumor necrosis factor receptor superfamily, member 11B (TNFRSF11B) is a strongly associated locus with bone mineral density, also discovered in GWAS, and the locus harboring LOC100128081 has also been reported in the context of a GWAS of SLE. FOS-like antigen 2 (FOSL2) gene encodes a leucine zipper protein that dimerizes with the JUN family proteins and forms the transcription factor complex activator protein 1 (AP-1). The FOS proteins have been implicated as regulators of cell proliferation, differentiation, and transformation (Cohen et al., 1989).

CUX2 (12q24):Huang et al., 2012 re-analyzed the original 2007 WTCCC study by using the 1000 Genomes imputation and reported refined variant rs1265564 in Cut-like homeobox 2 (CUX2) region for association with T1D. CUX2 is expressed exclusively in neural tissues. The protein belongs to the CUT homeobox family and contains three CUT domains and a homeodomain; both domains are DNA-binding motifs (Gingras et al., 2005). CUX2 gene has been shown to directly regulate the expression of NeuroD (Iulianella et al., 2008). NeuroD/BETA2, a transcription factor of the insulin gene, is reported to be associated with T1D in Asian descent (Iwata et al., 1999; Kavvoura \& Ioannidis, 2005). Thus CUX2 is a plausible candidate for exploration in T1D pathogenesis.

HTR1A (5p13-q13):Asad et al., 2012 confirmed the previously suggested association between the chromosome 5p13-q13 regions and T1D in Scandinavian families (Nerup et al., 2001). None of the previous GWAS have reported any association of 5p13-q13 with T1D. This recent study identified the 5-hydroxytryptamine receptor 1A (HTR1A) and the ring finger protein 180 (RFN180) genes to be associated with T1D in multiplex (Swedish and Danish) families. However, the conditional analysis indicated HTR1A has as a primary association with T1D. Both quantitative PCR and immunohistochemical analysis confirmed the presence of the HTR1A in human pancreas (Asad et al., 2012). The study suggests that HTR1A may affect T1D susceptibility by modulating the initial autoimmune attack or either islet regeneration, insulin release, or both. The HTR1A gene is known to encode for a G-protein coupled receptor specific for serotonin, which mediates cellular signaling via the amine serotonin (Barnes \& Sharp, 1999). The HTR1A receptor is mainly known to mediate signal transduction in neurons in the central nervous system (Lesurtel et al., 2008). However, serotonin is also produced in pancreatic islets of several different species (Sundler et al., 1980). Studies in rodent islets show inhibition of insulin secretion by serotonin (Zawalich et al., 2004). Sumatriptan (serotonin agonist) has an inhibitory effect on insulin secretion in humans (Coulie et al., 1998). Mohanan et al., 2006 reported a decrease in expression of HTR1A with increased insulin release during pancreatic regeneration. HTR1A also plays a role in the immune system. High level of protein expression 
has been reported in activated T-cells and low in resting T-cells; down regulates adenylate cyclase, which in turn regulates T-cell cytokine production and cytotoxicity (Aune et al., 1993). Hence polymorphisms in the HTR1A gene may affect insulin release and T-cell activity, thereby increases the risk of developing T1D.

\section{Conclusions}

This chapter provides a summary of recent advances in the identification of multiple variants associated with T1D. Genome wide association studies have revolutionized the field of autoimmune mediated disorders. In T1D only six genetic factors were well established before GWAS. GWAS has contributed greatly by expanding the number of established genetic variants to 57 genes. Most of these genes are novel and were not in any investigator's favorite list. For the first time there is real consensus on the role of specific genetic factors underpinning T1D pathogenesis.

The discoveries of genetic factors involved in the pathogenesis of T1D through GWAS present the first step in a much longer process leading to cure. Genes uncovered using this approach are indeed fundamental to disease biology and will define the key molecular pathways leading to cure of T1D. However, such genome wide scans can lack coverage in certain regions where it is difficult to genotype so it is possible that other loci with reasonable effect sizes remain to be uncovered.

To date most of T1D-associated variants have been discovered utilizing cohorts of European ancestry because the SNP arrays were designed to optimally capture the haplotype diversity in this ethnicity. Novel SNP arrays are needed with the same degree of capture in diverse populations to elucidate the full role of each locus in a worldwide context.

The next challenge is to resolve the specific causal variants and determine how they affect the expression and function of these gene products. The Next-Generation Sequencing (NGS) technology has opened new avenues to elucidate the role of coding and noncoding RNAs in health and disease and would speed up the identification of causative gene variants in T1D.

No doubt, the in vitro and in vivo biology of these genes will be fascinating areas of exploration for many scientists. Only after fully uncovering the functional context of T1D associated genes; these findings will show promise of use for preventive strategies.

\section{Acknowledgements}

This research was financially supported by grant from National Institute of Health (DP3 DK085708-01) and an Institute Development Award to the Center for Applied Genomics from the Children's Hospital of Philadelphia. 


\section{Author details}

Marina Bakay ${ }^{1}$, Rahul Pandey ${ }^{1}$ and Hakon Hakonarson ${ }^{1,2}$

1 Center for Applied Genomics, Children's Hospital of Philadelphia, Pennsylvania, USA

2 Department of Pediatrics, The University of Pennsylvania School of Medicine, Philadelphia, Pennsylvania, USA

\section{References}

[1] Agata, Y, Kawasaki, A, Nishimura, H, \& Honjo, T. (1996). Expression of the PD-1 antigen on the surface of stimulated mouse T and B-lymphocytes. Int Immunol. 1996 May; , 8(5), 765-772.

[2] Asad, S, Nikamo, P, Gyllenberg, A, \& Kockum, I. a novel type 1 diabetes susceptibility gene on chromosome 5PLoS One. 7(5)., 13-q13.

[3] Aune, T. M, Mcgrath, K. M, Sarr, T, \& Kelley, K. A. (1993). Expression of 5HT1a receptors on activated human $\mathrm{T}$ cells. Regulation of cyclic AMP levels and T cell proliferation by 5-hydroxytryptamine. J Immunol 1993 Aug; , 151, 1175-1183.

[4] Awata, T, Kawasaki, E, \& Tanaka, S. Japanese Study Group on Type 1 Diabetes Genetics ((2009). Association of type 1 diabetes with two loci on 12q13 and 16and the influence coexisting thyroid autoimmunity in Japanese. J Clin Endocrinol Metab. 2009 Jan; 94(1): 231-235., 13.

[5] Barnes NM \& Sharp T ((1999). A review of central 5-HT receptors and their function. Neuropharmacology 1999 Aug; , 38(8), 1083-1152.

[6] Barrett, J. C, Clayton, D. G, \& Concannon, P. Type 1 Diabetes Genetics Consortium ((2009). Genome-wide association study and meta-analysis find that over 40 loci affect risk of type 1 diabetes. Nat Genet. 2009 Jun; , 41(6), 703-707.

[7] Bell, G. I. Horita S \& Karam JH ((1984). A polymorphic locus near the human insulin gene is associated with insulin-dependent diabetes mellitus. Diabetes, $1984 \mathrm{Feb}$; , 33(2), 176-183.

[8] Bottini, N, Musumeci, L, Alonso, A, \& Mustelin, T. (2004). A functional variant of lymphoid tyrosine phosphatase is associated with type I diabetes. Nature genetics. 2004 Apr; , 36(4), 337-338.

[9] Bradfield, J. P, Qu, H. Q, Wang, K, \& Hakonarson, H. meta-analysis of six type 1 diabetes cohorts identifies multiple associated loci. PLoS Genet. 2011 Sep; 7(9):e1002293.

[10] Cambi A \& Figdor CG ((2003). Dual function of C-type lectin-like receptors in the immune system. Curr Opin Cell Biol. 2003 Oct; , 15(5), 539-46. 
[11] Clayton, D. G. (2009). Prediction and interaction in complex disease genetics: experience in type 1 diabetes. PLoS genetics. 2009 Jul; 5(7):e1000540.

[12] Cohen, D. R, Ferreira, P. C, Gentz, R, \& Curran, T. (1989). The product of a fos- related gene, Fra-1, binds cooperatively to the AP-1 site with Jun: transcription factor AP-1 is comprised of multiple protein complexes. Genes Dev. 1989 Feb; , 3(2), 173-184.

[13] Concannon, P, Onengut-gumuscu, S, \& Todd, J. A. Type 1 Diabetes Genetics Consortium. ((2008). A human type 1 diabetes susceptibility locus maps to chromosome 21q22.3. Diabetes. 2008 Oct; , 57(10), 2858-2861.

[14] Cooper, J. D, Smyth, D. J, Smiles, A. M, \& Todd, J. A. (2008). Meta-analysis of genomewide association study data identifies additional type 1 diabetes risk loci. Nature genetics. 2008 Dec; , 40(12), 1399-401.

[15] Cooper, J. D, Walker, N. M, \& Healy, B. C. Type I Diabetes Genetics Consortium. ((2009). Analysis of 55 autoimmune disease and type II diabetes loci: further confirmation of chromosomes 4q27,12q13.2 and 12q24.13 as type I diabetes loci, and support for a new locus, 12q13.q14.1. Genes and immunity. 2009 Dec ;10 Suppl 1:S95-120., 3.

[16] Coulie, B, Tack, J, Bouillon, R, \& Janssens, J. (1998). Hydroxytryptamine-1 receptor activation inhibits endocrine pancreatic secretion in humans. Am J Physiol 1998 Feb: 274(2 Pt 1): E, 317-320.

[17] Cudworth AG \& Woodrow JC(1975). Evidence for HL-A-linked genes in "juvenile" diabetes mellitus. Br Med J. 1975 Jul 19; , 3(5976), 133-5.

[18] Davison, L. J, Wallace, C, Cooper, J. D, \& Wallace, C. (2012). Long-range DNA looping and gene expression analyses identify DEXI as an autoimmune disease candidate gene. Hum Mol Genet. 2012 Jan 15; , 21(2), 322-33.

[19] Dontje, W, Schotte, R, Cupedo, T, \& Blom, B. (2006). Delta-like1-induced Notch 1 signaling regulates the human plasmacytoid dendritic cell versus $\mathrm{T}$ cell lineage decision through control of GATA-3 and Spi-B. Blood 2006 Mar; , 107(6), 2446-2452.

[20] Dubois, P. C, Trynka, G, Franke, L, \& Van Heel, D. A. (2010). Multiple common variants for celiac disease influencing immune gene expression. Nat Genet. 2010 Apr; , 42(4), 295-302.

[21] EURODIAB ACE Study Group(2000). Variation and trends in incidence of childhood diabetes in Europe. EURODIAB ACE Study Group. Lancet. 2000 Mar; , 355(9207), 873-876.

[22] Fung, E. Y, Smyth, D. J, Howson, J. M, \& Todd, J. A. (2009). Analysis of 17 autoimmune disease-associated variants in type 1 diabetes identifies 6q23/TNFAIP3 as a susceptibility locus. Genes and immunity. 2009 Mar; , 10(2), 188-91.

[23] Furuya, M, Tsuji, N, Endoh, T, \& Watanabe, N. (2002). A novel gene containing PDZ and LIM domains, PCD1, is overexpressed in human colorectal cancer. Anticancer Res. 2002 Nov-Dec; 22(6C): , 4183-4186. 
[24] Gateva, V, Sandling, J. K, Hom, G, \& Graham, R. R. replication study identifies TNIP1, PRDM1, JAZF1, UHRF1BP1 and IL10 as risk loci for systemic lupus erythematosus. Nat. Genet. 2009 Nov; , 41(11), 1228-1233.

[25] Gingras, H, Cases, O, Krasilnikova, M, \& Nepveu, A. (2005). Biochemical characterization of the mammalian Cux2 protein. Gene 2005 Jan; , 344, 273-285.

[26] Grant, S. F, Qu, H. Q, Bradfield, J. P, \& Hakonarson, H. (2009). Follow-up analysis of genome-wide association data identifies novel loci for type 1 diabetes. Diabetes. 2009 Jan; , 58(1), 290-295.

[27] Hakonarson, H, Grant, S. F, Bradfield, J. P, \& Polychronakos, C. association study identifies KIAA0350 as a type 1 diabetes gene. Nature. 2007 Aug 2; , 448(7153), 591-594.

[28] Hakonarson, H, Qu, H. Q, Bradfield, J. P, \& Polychronakos, C. (2008). A novel susceptibility locus for type 1 diabetes on Chr12q13 identified by a genome-wide association study. Diabetes. 2008 Apr; , 57(4), 1143-1146.

[29] Hirschfield, G. M, Xie, G, Lu, E, \& Siminovitch, K. A. (2012). Association of primary biliary cirrhosis with variants in the CLEC16A, SOCS1, SPIB and SIAE immunomodulatory genes. Genes Immun. 2012 Jun; , 13(4), 328-335.

[30] Howson, J. M, Rosinger, S, Smyth, D. J, \& Todd, J. A. (2011). Genetic analysis of adultonset autoimmune diabetes. Diabetes. 2011 Oct; , 60(10), 2645-2653.

[31] Huang, J, Ellinghaus, D, Franke, A, \& Li, Y. (2012). Genomes-based imputation identifies novel and refined associations for the Wellcome Trust Case Control Consortium phase 1 Data. Eur J Hum Genet. 2012 Jul; , 20(7), 801-805.

[32] Hung, C. N, Poon, W. T, Lee, C. Y, \& Chan, A. Y. (2012). A case of early-onset obesity, hypocortisolism, and skin pigmentation problem due to a novel homozygous mutation in the proopiomelanocortin (POMC) gene in an Indian boy. J Pediatr Endocrinol Metab. 25(1-2): 175-179.

[33] International HapMap Consortium(2003). The International HapMap Project. Nature. 2003 Dec; , 426(6968), 789-796.

[34] International HapMap Consortium(2005). A haplotype map of the human genome. Nature. 2005 Oct 27; , 437(7063), 1299-1320.

[35] Iulianella, A, Sharma, M, Durnin, M, \& Trainor, P. A. (2008). Cux2 (Cutl2) integrates neural progenitor development with cell-cycle progression during spinal cord neurogenesis. Development 2008 Feb; , 135(4), 729-741.

[36] Iwata, I, Nagafuchi, S, Nakashima, H, \& Niho, Y. (1999). Association of polymorphism in the NeuroD/BETA2 gene with type 1 diabetes in the Japanese. Diabetes. 1999 Feb; , 48(2), 416-419.

[37] Jagielska, D, Redler, S, Brockschmidt, F. F, \& Betz, R. C. (2012). Follow-Up Study of the First Genome-Wide Association Scan in Alopecia Areata: IL13 and KIAA0350 as 
Susceptibility Loci Supported with Genome-Wide Significance. J Invest Dermatol. 2012 Apr.

[38] Kang, S, Xu, H, Duan, X, \& Kennedy, G. C. (2000). PCD1, a novel gene containing PDZ and LIM domains, is overexpressed in several human cancers. Cancer Res. 2000 Sep; , 60(18), 5296-5302.

[39] Kavvoura FK \& Ioannidis JP(2005). Ala45Thr polymorphism of the NEUROD1 gene and diabetes susceptibility: a meta-analysis. Hum Genet. 2005 Feb; , 116(3), 192-199.

[40] Keutgens, A, Zhang, X, Shostak, K, \& Chariot, A. (2010). BCL-3 degradation involves its polyubiquitination through a FBW7-independent pathway and its binding to the proteasome subunit PSMB1. J Biol Chem. 2010 Aug 13; , 285(33), 25831-25840.

[41] Kim, S, Wairkar, Y. P, \& Daniels, R. W. DiAntonio A. ((2010). The novel endosomal membrane protein Ema interacts with the class C Vps-HOPS complex to promote endosomal maturation. Cell Biol. 2010 Mar; , 188(5), 717-734.

[42] Kim, S, \& Naylor, S. A. DiAntonio A. ((2012). Drosophila Golgi membrane protein Ema promotes autophagosomal growth and function. Proc Natl Acad Sci USA 2012 May; 109(18): E, 1072-1081.

[43] Krude, H, Biebermann, H, Luck, W, \& Gruters, A. (1998). Severe early-onset obesity, adrenal insufficiency and red hair pigmentation caused by POMC mutations in humans. Nat Genet. 1998 Jun; , 19(2), 155-157.

[44] Kutlu, B, Burdick, D, Baxter, D, \& Hood, L. (2009). Detailed transcriptome atlas of the pancreatic beta cell. BMC Med Genomics 2009 Jan; 2:3.

[45] Lesurtel, M, Soll, C, Graf, R, \& Clavien, P. A. (2008). Role of serotonin in the hepatogastro- Intestinal tract: an old molecule for new perspectives. Cell Mol Life Sci 2008 Mar; , 65(6), 940-952.

[46] Li, D. Kang Q \& Wang DM. ((2007). Constitutive coactivator of peroxisome proliferatoractivated receptor (PPAR-gamma), a novel coactivator of PPAR-gamma that promotes adipogenesis. Molec. Endocr. 2007 Oct; , 21(10), 2320-2333.

[47] Lindvall, J. M, Blomberg, K. E, Wennborg, A, \& Smith, C. I. (2005). Differential expression and molecular characterisation of Lmo7, Myo1e, Sash1, and Mcoln2 genes in Btkdefective B-cells. Cell Immunol. 2005 May; , 235(1), 46-55.

[48] Ludwig, M, \& Seuwen, K. (2002). Characterization of the human adenylyl cyclase gene family: cDNA, gene structure, and tissue distribution of the nine isoforms. J. Recept. Signal Transduct. Res. 2002 Feb-Nov; 22(1-4): 79-110.

[49] Manolio, T. A, Rodriguez, L. L, Brooks, L, \& Collins, F. S. (2007). New models of collaboration in genome-wide association studies: the Genetic Association Information Network. Nature genetics. 2007 Sep; , 39(9), 1045-1051. 
[50] Marquez, A, Varade, J, Robledo, G, \& Urcelay, E. (2009). Specific association of a CLEC16A/KIAA0350 polymorphism with NOD2/CARD15(-) Crohn's disease patients. Eur J Hum Genet. 2009 Oct; , 17(10), 1304-1308.

[51] Martinez, A, Perdigones, N, Cénit, M. C, \& Urcelay, E. (2010). Chromosomal region 16further evidence of increased predisposition to immune diseases. Ann Rheum Dis. 2010 Jan; 69(1): 309-311., 13.

[52] Mells, G. F, Floyd, J. A, Morley, K. I, \& Anderson, C. A. (2011). Genome-wide association study identifies 12 new susceptibility loci for primary biliary cirrhosis. Nat. Genet. 2011 Mar; , 43(4), 329-332.

[53] Mohanan, V. V, Khan, R, \& Paulose, C. S. (2006). Hypothalamic 5-HT functional regulation through 5-HT1A and 5-HT2C receptors during pancreatic regeneration. Life Sci 2006 Feb; , 78(14), 1603-1609.

[54] Mueller, P. W, Rogus, J. J, Cleary, P. A, \& Warram, J. H. (2006). Genetics of Kidneys in Diabetes (GoKinD) study: a genetics collection available for identifying genetic susceptibility factors for diabetic nephropathy in type 1 diabetes. J Am Soc Nephrol. $2006 \mathrm{Jul} ;$, 17(7), 1782-1790.

[55] Nakamura, H, Mukai, M, Komatsu, K, \& Miyoshi, J. (2005). Transforming growth factor-beta1 induces LMO7 while enhancing the invasiveness of rat ascites hepatoma cells. Cancer Lett. 2005 Mar; , 220(1), 95-99.

[56] Nepomuceno-silva, J. L, De Melo, L. D, Mendonçã, S. M, \& Lopes, U. G. (2004). RJLs: a new family of Ras-related GTP-binding proteins. Gene 2004 Mar; , 327(2), 221-232.

[57] Nerup, J, Platz, P, Andersen, O. O, \& Svejgaard, A. (1974). HLA antigens and diabetes mellitus. Lancet. 1974 Oct; , 2(7885), 864-866.

[58] Nerup, J. Pociot F \& European Consortium for IDDM Studies. ((2001). A genomewide scan for type 1-diabetes susceptibility in Scandinavian families: identification of new loci with evidence of interactions. Am J Hum Genet 2001 Dec; , 69(6), 1301-1313.

[59] Nischwitz, S, Cepok, S, Kroner, A, \& Weber, F. (2011). More CLEC16A gene variants associated with multiple sclerosis. Acta Neurol Scand 2011 Jun; , 123(6), 400-406.

[60] Nistico, L, Buzzetti, R, Pritchard, L. E, \& Todd, J. A. (1996). The CTLA-4 gene region of chromosome $2 \mathrm{q} 33$ is linked to, and associated with, type 1 diabetes. Belgian Diabetes Registry. Human molecular genetics. 1996 Jul; , 5(7), 1075-1080.

[61] Okada, M, Cheeseman, I. M, Hori, T, \& Fukagawa, T. (2006). The CENP-H-I complex is required for the efficient incorporation of newly synthesized CENP-A into centromeres. Nature Cell Biol. 2006 May; , 8(5), 446-457.

[62] Onate, S. A, \& Tsai, S. Y. Tsai MJ. \& O’Malley BW. ((1995). Sequence and characterization of a coactivator for the steroid hormone receptor superfamily. Science 1995 Nov; , 270(5240), 1354-1357. 
[63] Onkamo, P, Vaananen, S, Karvonen, M, \& Tuomilehto, J. (1999). Worldwide increase in incidence of Type I diabetes--the analysis of the data on published incidence trends. Diabetologia. 1999 Dec; , 42(12), 1395-1403.

[64] Ooshio, T, Irie, K, Morimoto, K, \& Takai, Y. (2004). Involvement of LMO7 in the association of two cell-cell adhesion molecules, nectin and E-cadherin, through afadin and alpha-actinin in epithelial cells. J. Biol. Chem. 2004 Jul; , 279(30), 31365-31373.

[65] Perou, C. M, Sørlie, T, Eisen, M. B, \& Botstein, D. (2000). Molecular portraits of human breast tumours. Nature. 2000 Aug; , 406(6797), 747-752.

[66] Qu, H. Q, Bradfield, J. P, Li, Q, \& Polychronakos, C. (2010). In silico replication of the genome-wide association results of the Type 1 Diabetes Genetics Consortium. Human molecular genetics. 2010 Jun 15; , 19(12), 2534-2538.

[67] Reddy, M. V, Wang, H, Liu, S, \& She, J. X. (2011). Association between type 1 diabetes and GWAS SNPs in the southeast US Caucasian population. Genes Immun. 2011 Apr; , 12(3), 208-212.

[68] Redondo, M. J, Yu, L, Hawa, M, \& Leslie, R. D. (2001). Heterogeneity of type I diabetes: analysis of monozygotic twins in Great Britain and the United States. Diabetologia. 2001 Mar; , 44(3), 354-362.

[69] Rozenblum, E, Vahteristo, P, Sandberg, T, \& Kallioniemi, O. P. (2002). A genomic map of a 6-Mb region at 13q21-q22 implicated in cancer development: identification and characterization of candidate genes. Hum. Genet. 2002 Feb; , 110(2), 111-121.

[70] Rich, S. S. (1990). Mapping genes in diabetes. Genetic epidemiological perspective. Diabetes. 1990 Nov; , 39(11), 1315-1319.

[71] Robinson, M. J, Sancho, D, \& Slack, E. C. Reis e Sousa C. ((2006). Myeloid C-type lectins in innate immunity. Nat Immunol. 2006 Dec; , 7(12), 1258-1265.

[72] Sang, Y, \& Zong, W. Yan J \& Liu M. ((2012). The Correlation between the CLEC16A Gene and Genetic Susceptibility to Type 1 Diabetes in Chinese Children. Int J Endocrinol. 2012:245384.

[73] Santos, M. A, Sarmento, L. M, Rebelo, M, \& Demengeot, J. (2007). Notch1 engagement by Delta-like-1 promotes differentiation of B lymphocytes to antibody-secreting cells. Proc. Natl. Acad. Sci. USA 2007 Sep; , 104(39), 15454-15459.

[74] Sasaki, M, Tsuji, N, Furuya, M, \& Watanabe, N. (2003). PCD1, a novel gene containing PDZ and LIM domains, is overexpressed in human breast cancer and linked to lymph node metastasis. Anticancer Res. 2003 May; 23(3B): , 2717-2721.

[75] Semenova, E, Wang, X, Jablonski, M. M, \& Tilghman, S. M. (2003). An engineered 800 kilobase deletion of Uchl3 and Lmo7 on mouse chromosome 14 causes defects in viability, postnatal growth and degeneration of muscle and retina. Hum Mol Genet 2003 Jun; , 12(11), 1301-1312. 
[76] Singal DP \& Blajchman MA(1973). Histocompatibility (HL-A) antigens, lymphocytotoxic antibodies and tissue antibodies in patients with diabetes mellitus. Diabetes. 1973 Jun; , 22(6), 429-432.

[77] Skinningsrud, B, Husebye, E. S, Pearce, S. H, \& Undlien, D. E. (2008). Polymorphisms in CLEC16A and CIITA at 16are associated with primary adrenal insufficiency. J. Clin. Endocrinol. Metab., 2008 Sep; 93(9): 3310-3317., 13.

[78] Smyth, D. J, Cooper, J. D, Bailey, R, \& Todd, J. A. association study of nonsynonymous SNPs identifies a type 1 diabetes locus in the interferon-induced helicase (IFIH1) region. Nature genetics. 2006 Jun; , 38(6), 617-619.

[79] Smyth, D. J, Plagnol, V, Walker, N. M, \& Todd, J. A. (2008). Shared and distinct genetic variants in type 1 diabetes and celiac disease. The New England journal of medicine. 2008 Dec 25; , 359(26), 2767-2777.

[80] Steyn, N. P, Lambert, E. V, \& Tabana, H. (2009). Conference on "Multidisciplinary approaches to nutritional problems". Symposium on "Diabetes and health". Nutrition interventions for the prevention of type 2 diabetes. Proc. Nutr. Soc. 2009 Feb; , 68(1), 55-70.

[81] Su, Y, Büchler, P, Gazdhar, A, \& Friess, H. (2006). Pancreatic regeneration in chronic pancreatitis requires activation of the notch signaling pathway. J. Gastrointest. Surg. 2006 Nov; , 10(9), 1230-1241.

[82] Sundler, F, Hakanson, R, Loren, I, \& Lundquist, I. (1980). Amine storage and function in peptide hormone-producing cells. Invest Cell Pathol. 1980 Jan-Mar; , 3(1), 87-103.

[83] Todd, J. A, Walker, N. M, Cooper, J. D, \& Clayton, D. G. (2007). Robust associations of four new chromosome regions from genome-wide analyses of type 1 diabetes. Nature genetics. 2007 Jul; , 39(7), 857-864.

[84] Torchia, J, Rose, D. W, Inostroza, J, \& Rosenfeld, M. G. (1997). The transcriptional coactivator $\mathrm{p} / \mathrm{CIP}$ binds CBP and mediates nuclear-receptor function. Nature. 1997 Jun $12 ;$, 387(6634), 677-684.

[85] Trachtulec, Z, Hamvas, R. M, Forejt, J, \& Klein, J. (1997). Linkage of TATA-binding protein and proteasome subunit $\mathrm{C} 5$ genes in mice and humans reveals synteny conserved between mammals and invertebrates. Genomics. 1997 Aug; , 44(1), 1-7.

[86] Vella, A, Cooper, J. D, Lowe, C. E, \& Todd, J. A. (2005). Localization of a type 1 diabetes locus in the IL2RA/CD25 region by use of tag single-nucleotide polymorphisms. Am J Hum Genet. 2005 May; , 76(5), 773-779.

[87] Wallace, C, Smyth, D. J, Maisuria-armer, M, \& Clayton, D. G. (2010). The imprinted DLK1-MEG3 gene region on chromosome $14 \mathrm{q} 32.2$ alters susceptibility to type 1 diabetes. Nat Genet. 2010 Jan; , 42(1), 68-71.

[88] Wellcome Trust Case Control Consortium: WTCCC ((2007). Genome-wide association study of 14,000 cases of seven common diseases and 3,000 shared controls. Nature. 2007 Jun; , 447(7145), 661-678. 
[89] Wang, K, Baldassano, R, Zhang, H, \& Hakanarson, H. (2010). Comparative genetic analysis of inflammatory bowel disease and type 1 diabetes implicates multiple loci with opposite effects. Human molecular genetics. 2010 May; , 19(10), 2059-2067.

[90] Wong, S. T, Trinh, K, Hacker, B, \& Storm, D. R. (2000). Disruption of the type III adenylyl cyclase gene leads to peripheral and behavioral anosmia in transgenic mice. Neuron. 2000 Sep; , 27(3), 487-497.

[91] Wu, X, Zhu, X, Wang, X, \& Liu, Y. (2009). Intron polymorphism in the KIAA0350 gene is reproducibly associated with susceptibility to type 1 diabetes (T1D) in the Han Chinese population. Clin Endocrinol (Oxf). 2009 Jul; , 71(1), 46-49.

[92] $\mathrm{Wu}, \mathrm{X}, \mathrm{Li}, \mathrm{J}$, Chen, C, \& Gao, Y. (2012). Involvement of CLEC16A in activation of astrocytes after LPS treated. Neurochem Res. 2012 Jan; , 37(1), 5-14.

[93] Yamada, A, Irie, K, Fukuhara, A, \& Takai, Y. (2004). Requirement of the actin cytoskeleton for the association of nectins with other cell adhesion molecules at adherens and tight junctions in MDCK cells. Genes Cells 2004 Sep; , 9(9), 843-855.

[94] Yamashita, H, Awata, T, \& Kawasaki, E. Japanese Study Group on Type 1 Diabetes Genetics. ((2011). Analysis of the HLA and non-HLA susceptibility loci in Japanese type 1 diabetes. Diabetes Metab Res Rev. 2011 Nov; , 27(8), 844-848.

[95] Yanagisawa, Y, \& Ito, E. Yuasa Y \& Maruyama K ((2002). The human DNA methyltransferases DNMT3A and DNMT3B have two types of promoters with different CpG contents. Biochim. Biophys. Acta 2002 Sep; , 1577(3), 457-465.

[96] Yoo, A. S, Staahl, B. T, Chen, L, \& Crabtree, G. R. (2009). MicroRNA-mediated switching of chromatin-remodelling complexes in neural development. Nature. 2009 Jul; , 460(7255), 642-646.

[97] Zawalich, W. S, Tesz, G. J, \& Zawalich, K. C. (2004). Effects of prior 5-hydroxytryptamine exposure on rat islet insulin secretory and phospholipase $\mathrm{C}$ responses. Endocrine. $2004 \mathrm{Feb} ;$, 23(1), 11-16.

[98] Zhang, Z, Cheng, Y, Zhou, X, \& Zhang, X. (2011). Polymorphisms at 16are associated with systemic lupus erythematosus in the Chinese population. J Med. Genet. 2011 Jan; 48(1): 69-72., 13.

[99] Zoledziewska, M, Costa, G, Pitzalis, M, \& Marrosu, M. G. (2009). Variation within the CLEC16A gene shows consistent disease association with both multiple sclerosis and type 1 diabetes in Sardinia. Genes Immun. 2009 Jan; , 10(1), 15-17.

[100] Zuvich, R. L, Bush, W. S, Mccauley, J. L, \& Haines, J. L. (2011). Interrogating the complex role of chromosome 16in multiple sclerosis susceptibility: independent genetic signals in the CIITA-CLEC16A-SOCS1 gene complex. Hum. Mol. Genet., 2011 Sep; 20(17): 3517-3524., 13. 
